\title{
Description Of Compliance With Bontobahari Mother Consuming Vitamin A In Bontobahari Puskesmas
}

\author{
Iramayasari $^{1 *}$, Irmawati $^{2}$ \\ ${ }^{1,2}$ Department of Midwifery, Stikes Panrita Husada Bulukumba, Indonesia
}

Corresponding author: Iramayasari

Email: Iramaya010185@gmail.com

\begin{abstract}
Based on data from the World Health Organization ((WHO), it is stated that mothers and babies who are breastfed will benefit from giving one high-dose Vitamin A capsule (200,000 IU). Various studies have shown that giving high doses of Vitamin A capsules (200,000 IU) previously recommended it was deemed inadequate. Vitamin A is one of the vitamins needed and is useful for the growth of cells, teeth, bones, development of vision, and increasing body resistance to infection. The aim of the research was to know the description of the compliance of postpartum mothers in consuming vitamin $\mathrm{A}$ at the Bontobahari Community Health Center in 2018. This research was conducted using a descriptive survey research method, which is a research method with the aim of knowing the description or description of health problems in the form of risk factors and effects. The technique used in this research is the Accidental Sampling technique. The population and sample in this study were part of the postpartum mothers in the Bontobahari puskesmas area, totaling 3 people. From the research that has been done, it is found that out of 33 respondents, 24 people $(72.7 \%$ ) obedient to consuming Vitamin A, and 9 people (27.3\%) who are not obedient to consuming Vitamin A. The conclusion of this research. Suggestions from the results of this study are that the results of this research can be used as information and input to postpartum mothers regarding adherence to consuming Vitamin A.
\end{abstract}

Keywords: Compliance, Postpartum Mother, Vitamin A 


\section{PENDAHULUAN}

Masa nifas adalah masa dimulai beberapa jam sesudah lahirnya plasenta sampai 6 minggu setelah melahirkan. Masa nifas dimulai setelah kelahiran plasenta dan berakhir ketika alat-alat kandungan kembali seperti keadaan sebelum hamil yang berlangsung kira-kira 6 minggu. Masa nifas merupakan masa selama persalinan dan segera setelah kelahiran yang meliputi mingguminggu berikutnya pada waktu saluran reproduksi kembali ke keadaan tidak hamil yang normal. Masa nifas adalah masa setelah seorang ibu melahirkan bayi yang dipergunakan untuk memulihkan kesehatannya kembali yang umumnya memerlukan waktu 6-12 minggu. (Marni.2015). Masa nifas adalah masa sesudah persalinan dan kelahiran bayi, plasenta, serta selaput yang diperlukan untuk memulihkan kembali organ kandungan seperti sebelum hamil dengan waktu kurang lebih 6 minggu. (saleha sitti,2013).

Setelah persalinan, terjadi beberapa perubahan penting diantaranya makin menigkatnya pembentukan urine untuk mengurangi hemodilusi darah, terjadi penyerapan beberapa bahan tertentu melalui pembuluh darah vena sehingga terjadi peningkatan suhu tubuh sekitar $0,5^{\circ} \mathrm{C}$ yang bukan merupakan keadaan yang patologis pada hari pertama. Perlukaan karna persalinan merupakan tempat masuknya kuman kedalam tubuh sehingga menimbulkan infeksi pada masa nifas (Chandra Ayu Ida Manuaba, 2010). Badan Kesehatan Dunia WHO menyatakan bahwa ibu dan bayi yang disusuinya akan mendapatkan mamfaat dari pemberian satu kapsul dosis tinggi (200.000 IU). Pada Bulan Desember 2011 sampai sekarang consultative mengeluarkan rekomendasi bahwa seluruh ibu nifas seharusnya menerima 400.000 SI atau dua kapsul dosis tinggi 200.000 SI, target cakupan pemberian Vitamin A pada ibu nifas tahun 2012 masih 71,50\%, capaian pemberian Vitamin A pada ibu nifas Di Indonesia tahun 2012 sebesar 70,5\%.

Pada pasca persalinan atau Masa Nifas ibu yang mendapatkan Vitamin A hanya 52,2\% (rentang: 33,2\% di Sumatra utara dan 65,8\% di jawa tengah ). berdasarkan tingkat pendidikan, cakupan ibu nifas yang tidak sekolah mendapatkan kapsul Vitamin A hanya sebanyak 31\% dibandingkan dengan yang tamat PT 62,5\%. Demikian pula kesenjangan yang cukup lebar antara ibu nifas di perkotaan dan pedesaan, serta menurut tingkat pengeluaran. (Riskesdas,2010).

Berdasarkan data dari provinsi Sulawesi Selatan, jumlah kematian ibu di laporkan oleh Dinas Kesehatan kabupaten/kota pada tahun 2015 dari 448 puskesmas angka kematian ibu sebesar 86 orang/100.000 kelahiran hidup, pada tahun 2016 kematian ibu nifas menjadi 62 
orang/100.000 kelahiran hidup. Berdasarkan data dari Dinas Kesehatan Kabupaten Bulukumba tahun 2015 diperoleh 6136 (84,9\%), ibu nifas yang mendapatkan vitamin A sebanyak 5536 orang Sedangkan Berdasarkan data dari Puskesmas Bontobahari pada tahun 2015 jumlah ibu nifas sebanyak 438 jiwa, yang diberikan Vitamin A sebanyak 412 jiwa, tahun 2016 jumlah ibu nifas sebanyak 444 jiwa, yang diberikan Vitamin A sebanyak 427 jiwa, tahun 2017 jumlah ibu nifas sebanyak 395, yang diberikan Vitamin A sebanyak 334 jiwa dan tahun 2018 bulan januari sampai Mei jumlah ibu nifas sebanyak 50 jiwa, yang diberikan Vitamin A sebanyak 50 Jiwa.

Vitamin A penting untuk ibu melahirkan pada masa nifas ini. Karena persiapan ASI untuk sang bayi sangatlah penting. Sehingga asupan suplemen Vitamin A bisa dibeli baik berupa kapsul obat yang bisa langsung diminum, atau secara alami dari buah dan sayuran. Dengan mengkomsumsi Vitamin A yang cukup dalam masa nifas maka mencegah bayi kekurangan Vitamin A dalam masa pertumbuhannya maksimal sampai 2 tahun. Cacat tubuh pun bisa dihindari. Gejala anak mudah sakit karena sang ibu tidak segera mengkomsumsi makanan bergizi semasa menyusui ini. Perhatikan bahwa kekurangan Vitamin A akan mengakibatkan anak mudah terserang campak, diare, atau penyakit infeksi lainnya. (Depkes RI, 2011).

Jika kekurangan Vitamin A berkelanjutan, maka akan mengalami xeropthalmia yang dapat mengakibatkan kebutaan,selain itu kekurangan Vitamin A akan mengakibatkan Anemia karena sumsun tulang belakang tempat produksi sel darah merah tidak berfungsi secara normal. Jadi pencegahan kekurangan Vitamin A adalah upaya-upaya untuk memenuhi kebutuhan Vitamin A yang cukup bagi tubuh serta mencegah penyakit infeksi, terutama diare dan campak.(Dra.Wirakusumah Pandi Emma,2010). Kepatuhan adalah suatu bentuk perilaku yang timbul akibat adanya interaksi antara petugas kesehatan dan pasien sehingga pasien mengerti rencana dengan segala konsekwensinya dan menyetujui remcana tersebut serta melaksanakannya (Kemenkes R I,2011). Kepatuhan ibu nifas dalam mengkomsumsi Vitamin A sangat diperoleh oleh peran tenaga kesehatan khususnya bidan memiliki peran dan fungsi sebagai pendidik. Dalam hal ini bidan memberikan pendidikan kesehatan tentang vitamin A kepada ibu nifas, agar pengetahuan ibu nifas tentang Vitamin A bertambah. Selain sebagai pendidik bidan juga sebagai pemberi pelayanan khususnya pemberian Vitamin A kepada Ibu Nifas (norma jeepi,2015).

Berdasarkan penelitian yang dilakukan oleh Annisa kusuma (2012) yang berjudul "Faktorfaktor yang Mempengaruhi Tingkat Kepatuhan Ibu Nifas Mengkomsumsi Vitamin A di 
Puskesmas Mandar, Sulawesi selatan” didapatkan hasil dari 30 ibu nifas diantaranya sembilang ibu nifas (38,2\%) patuh mengkomsumsi Vitamin A dan 21 ibu nifas $(61,8 \%)$ tidak patuh dalam mengkomsumsi Vitamin A. Pemberian Vitamin A pada masa nifas sudah diterapkan disetiap pelayanan kesehatan termasuk Puskesmas Bontobahari, namun perlu dikaji apakah ibu nifas patuh atau tidak patuh dalam mengkomsumsi Vitamin A yang diberikan.

\section{BAHAN DAN METODE}

\section{Desain Penelitian}

Jenis penelitian yang digunakan adalah penelitian deskriptif yang merupakan pencarian fakta dengan interpretasi yang tepat. Ciri-ciri metode deskriptif yaitu memusatkan perhatian pada permasalahan yang ada pada saat penelitian di lakukan atau permasalahan yang diselidiki sebagai mana adanya, di iringi, dengan interpretasi rasional yang seimbang, pekerjaan peneliti bukan saja memberikan gambaran terhadap fenomena-fenomena, tetapi juga menerangkan hubungan, menguji hipotesis, membuat prediksi, serta mendapat makna dan implikasi dari suatu masalah.

\section{Populasi dan Sampel}

Populasi adalah wilayah generalisasi yang terdiri atas: obyek/subyek yang mempunyai kualitas dan karakteristik tertentu yang ditetapkan oleh peneliti untuk dipelajari dan kemudian ditarik kesimpulannya (Sandu Siyoto dan Ali Sodik, 2015). Populasi dalam penelitian ini adalah seluruh ibu nifas pada bulan januari sampai Mei yaitu sebanyak 50 orang di wilayah puskesmas Bontobahari. Sampel adalah Sebagian dari jumlah dan karakteristik yang dimiliki oleh populasi tersebut, ataupun bagian kecil dari angota populasi yang diambil menurut prosedur tertentu sehingga dapat mewakili populasinya (Sandu Siyoto dan Ali Sodik 2015). Sampel dalam penelitian ini adalah sebagian dari populasi yaitu 33 ibu nifas di wilayah puskesmas Bontobahari.

\section{Instrumen Penelitian}

Instrument penelitian adalah alat-alat yang digunakan untuk pengumpulan data (Notoatmodjo, 2010). Instrument penelitian ini dengan cara observasi yaitu pengamatan yang meliputi kegiatan pemantauan perhatian terhadap subjek dengan menggunakan seluruh indera. Instrumen yang digunakan dalam observasi dapat berupa pedoman pengamatan. 


\section{Tehnik Pengumpulan Data}

Pengumpulan data menggunakan data Primer yang diambil langsung dari sumber asli atau pihak pertama secara langsung. pengumpulan data pada penelitian ini dengan cara observasi langsung kepada ibu nifas yang akan mengkomsumsi Vitamin A.

\section{Analisis Data}

Rencana pelaksanaan analisis data dilakukan secara deskrptif sebagaimana dalam hidayat (2010) dengan menggunakan program SPSS

\section{HASIL}

Berdasarkan Tabel 1 menunjukkan bahwa dari 33 responden pada kategori umur $<20$ sebanyak 7 orang (21,2\%), sedangkan responden kategori umur 21-35 sebanyak 17 orang $(51,5 \%)$ dan kategori umur $>35$ sebayak 9 orang $(27,3 \%)$.

\section{Tabel 1. Distribusi Frekuensi Responden Berdasarkan umur}

\begin{tabular}{ccc}
\hline Umur & Frequency & Percent \\
\hline$<20$ & 7 & 21.2 \\
\hline $21-35$ & 17 & 51.5 \\
\hline 35 & 9 & 27.3 \\
\hline Total & $\mathbf{3 3}$ & $\mathbf{1 0 0 . 0}$ \\
\hline
\end{tabular}

Berdasarkan Tabel 2 menunjukkan bahwa dari 33 Responden yang patuh sebanyak 24 orang (72,7) dan responden yang tidak patuh sebanyak 9 orang (27.3).

\section{Tabel 2. Gambaran Kepatuhan Ibu Nifas Dalam Mengkomsumsi Vitamin A}

\begin{tabular}{lcl}
\hline Variabel & Frequency & Percent \\
\hline Patuh & 24 & 72,7 \\
\hline tidak patuh & 9 & 27.3 \\
\hline Total & $\mathbf{3 3}$ & $\mathbf{1 0 0 . 0}$ \\
\hline
\end{tabular}

Berdasarkan Tabel 3 menunjukkan bahwa dari 33 Responden umur <20 yang patuh 7 orang dan yang tidak patuh $0(0,0 \%)$ total 7 orang, umur $21-35$ yang patuh $10(58,8 \%)$ orang dan tidak patuh $7(41, \%)$ orang total 17 orang, dan umur $>35$ yang patuh $7(77,8 \%)$ orang dan yang tidak patuh $2(22,2 \%)$ orang total 9 orang. 
Tabel 3. Distribusi Frekuensi antara umur dengan kepatuhan Dipuskesmas Bontobahari

\begin{tabular}{|c|c|c|c|c|c|}
\hline & \multicolumn{2}{|c|}{ Kepatuhan } & \multirow[t]{2}{*}{ Total } \\
\hline & & & patuh & tidak patuh & \\
\hline \multirow{6}{*}{ Umur } & \multirow{2}{*}{$<20$} & Count & 7 & 0 & 7 \\
\hline & & $\%$ within umur & $100.0 \%$ & $0.0 \%$ & $100.0 \%$ \\
\hline & \multirow{2}{*}{$21-35$} & Count & 10 & 7 & 17 \\
\hline & & $\%$ within umur & $58.8 \%$ & $41.2 \%$ & $100.0 \%$ \\
\hline & \multirow{2}{*}{$>35$} & Count & 7 & 2 & 9 \\
\hline & & $\%$ within umur & $77.8 \%$ & $22.2 \%$ & $100.0 \%$ \\
\hline \multirow{2}{*}{ Total } & & Count & 24 & 9 & 33 \\
\hline & & $\%$ within umur & $72.7 \%$ & $27.3 \%$ & $100.0 \%$ \\
\hline
\end{tabular}

\section{PEMBAHASAN}

Dalam penelitian ini didapatkan bahwa dari 33 responden, jumlah responden yang patuh sebanyak 24 orang $(72,7 \%)$ dan responden yang tidak patuh sebanyak 9 orang $(27.3 \%)$. Responden yang dari 33 responden menunjukkan bahwa responden pada kategori umur $<20$ sebanyak 7 orang $(21,2 \%)$, sedangkan responden kategori umur 21-35 sebanyak 17 orang $(51,5 \%)$ dan kategori umur $>35$ sebayak 9 orang $(27,3 \%)$. Ibu Nifas yang memiliki kepatuhan tentang mengkomsumsi Vitamin A menunjukkan bahwa 72,7\% dari responden dalam kategori patuh dalam mengkomsumsi vitamin A. data yang diperoleh menggambarkan bahwa sebagian besar responden yang paling banyak kategori umur 21-35 sebanyak 17 orang (51,5\%). Bahwa dari 33 Responden menunjukkan bahwa umur $<20$ yang patuh 7 orang dan yang tidak patuh 0 $(0,0 \%)$ total 7 orang, umur $21-35$ yang patuh $10(58,8 \%)$ orang dan tidak patuh $7(41, \%)$ orang total 17 orang, dan umur $>35$ yang patuh $7(77,8 \%)$ orang dan yang tidak patuh $2(22,2 \%)$ orang total 9 orang.

Berdasarkan hasil penelitian menurut Norma Jeepi mengemukakan bahwa hasil penelitian pada variabel umur didapati hasil bahwa analisis faktor yang berhubungan dengan kepatuhan ibu nifas dalam mengkomsumsi Vitamin A didapatkan hasil bahwa umur tidak berhubungan dengan kepatuhan seseorang. Namun hasil penelitian ini kontradiktif dengan teori notoatmotmodjo (2010) dan juga tidak sesuai dengan teori yang menyampaikan bahwa mereka yang berusia tua umumnya lebih bertanggung jawab, lebih tertib dan lebih bermoral serta lebih berbakti bila dibandingkan dengan usia muda, karena kedewasaannya untuk beradaptasi perilaku tidak hanya disebabkan karena bertambahnya usia tetapi juga dipengaruhi oleh 
lingkungan yang ada disekitarnya sepeti ketepaparan dengan sumber imformasi, wawasan serta pengaaman yang berbeda-beda pada masing-masing individu.

Menurut asumsi peneliti, dari hasil secara keseluruhan penelitian mengenai Gambaran Kepatuhan Ibu Nifas dalam megkomsumsi Vitamin A di Puskesmas Bontobahari Tahun 2018 secara umum dinilai patuh dalam mengkomsumsi Vitamin A. Dan dari 33 responden yang tidak patuh dalam mengkomsumsi vitaamin A dipengaruhi oleh peran tenaga kesehatan dan dukungan dari keluarga atau suami.

\section{KESIMPULAN DAN SARAN}

Berdasarkan dari hasil yang dilakukan di wilayah puskesmas Bontobahari Tahun 2018 maka peneliti dapat mengambil kesimpulan bahwa kepatuhan ibu nifas dalam mengkomsumsi Vitamin A dalam kategori patuh terdapat 24 orang (72,7\%), kepatuhan ibu nifas dalam mengkomsumsi Vitamin A dalam kategori tidak patuh terdapat 9 orang (27,3\%). Hasil penelitian ini dapat dijadikan untuk dikemukakan dan masukan mahasiswa serta segala institusi yang terkait untuk mengetahui tentang pemberian Vitamin A pada masa nifas, Sebagai sumbangan ilmiah dan bahan bacaan untuk penelitian selanjutnya. Dan Bermanfaat sebagai perbandingan bagi peneliti-peneliti selanjutnya.

\section{DAFTAR PUSTAKA}

Astutik Yuli Reni, (2015). Buku Ajar Asuhan Kebidanan Masa Nifas Dan menyusui. jakarta: TIM

Aziz Alimul Hidayat, (2011). Metode Penelitian Kebidanan dan Tehnik Analisis Data, Jakarta : Medika Salemba

Dr, Sandu Siyoto \& M. Ali Sodik. (2015). Dasar Metodologi Penelitian. Yogyakarta: Literasi Media Publishing

Heryani Reni, (2012). Asuhan Kebidanan Ibu Nifas dan Menyusui. Jakarta: Trans Info Media

( HYPERLINK "http://id.wikipedia.org/wiki/kepatuhan.15januari2018" http://id.wikipedia.org/wiki/kepatuhan.15januari2018 )

Ida Ayu Chandranita et al, (2010). Ilmu kebidanan, penyakitn kandunngan, dan $\quad K b$. Jakarta: EGC

Laporan Dinas Kesehatan Bulukumba, 2015 
Laporan Hasil Rekap Vit A di Puskesmas Bontobahari 2015,2016,2017

Mansyur, Nurliana., \& Dahlan, Kasrina. (2014). Buku Ajar Asuhan Kebidanan Masa Nifas. Selaka Media: jatim

Margiyanti Jeepi Norma, \& Hutabarat Oktapiani Sari, (2015). Faktor-faktor yang berhubungan dengan kepatuhan ibu Nifas Mengkomsumsi Vitamin A. (diakses 15 juli 2018)

Pdf. (2010) Laporan Riskesdas, Diakses pada tanggal 13 juli 2018

Pdf. Profil Kesehatan

Saleha Sitti, (2009). Asuhan Kebidanan Pada Masa Nifas. Jakarta: Salemba Medika

Sari Puspita Eka, \& Kurnia Dwi Rimdani, (2014). Asuhan Kebidanan Masa Nifas (Posnatal care). Jakarta: Salemba Medika 